\title{
The Possibility of Conducting Experiments on Animals. Moral Theologian's Reflections
}

\begin{abstract}
Summary
The Catholic moral theology acknowledges a person's right to use animals in compliance with their nature, while putting the emphasis on the obligation to treat them with proper sensitivity and kindness. This right includes the possibility to conduct experiments on animals. Such experiments are allowed after meeting a range of conditions. Justifiable hopes for scientific development or for achieving practical goals are required. Also, the number of used animals should be limited and the pain and stress the animals feel ought to be minimized. A right balance should be maintained between those factors. Moreover, moral theology elevates the value of intentions, i.e., the objective for which the test results will be used. It can modify the moral classification of experiments, which on their own are good or neutral.
\end{abstract}

Keywords: $3 \mathrm{R}$ rule, experiments on animals, moral theology

Słowa kluczowe: eksperymenty na zwierzętach, teologia moralna, zasada 3R

\section{Introduction}

Carrying out experiments on animals raises a number of ethical dilemmas. They are linked to the complexity of this problem and the necessity to stand either for the protection of animals or for the

${ }^{1}$ Katolicki Uniwersytet Lubelski im. Jana Pawła II, Instytut Teologii Moralnej, Al. Racławickie 14, 20-950 Lublin, e-mail: ksmykowski@gmail.com 
development of knowledge and medical practice which contributes to curing illnesses and saving human lives.

Although people have the right to use animals for their own benefit if it does not directly deny the animals' own nature, not all experiments carried out on animals can be considered morally permissible. Such a statement is explicitly formulated by the Catechism of the Catholic Church: "Medical and scientific experimentation on animals is a morally acceptable practice, if it remains within reasonable limits and contributes to caring for or saving human lives" (Katechizm 2002 2417). It should be noted that small but significant changes have been made to the document from its first edition. The original notation suggested, sort of a priori, that experiments on animals always contribute to human welfare and thus are fair. In contrast, the revised version emphasizes the need to prove this usefulness (Hendricks 2001: 54). Therefore, according to the Catechism's prescriptions, we need to closely observe the elements of biomedical research and critically analyze them to be able to fully present the moral assessment of particular types of experiments.

The Magisterium of the Church did not state in any of its documents a complete list of the criteria which would consider a medical or scientific experiment using animals to be morally fair. In some texts, however, requirements which are to be met have been specified either directly or indirectly. The rest of the criteria should be derived from the basic principles of moral theology which define the sources of morality for human acts. To this end, the achievements of philosophical ethics under which relatively numerous studies on this topic arose and the ethical publications of experimental scientists themselves are also useful.

The guiding rule which should be in force when performing experiments on animals should be to recognize the animals' moral status which makes them the object of human responsibility (Morciniec 2005: 90). This fundamental demand which was frequently promoted by the Church has met with understanding among researchers as well. This results in expanding the 3R rule (refinement methods to reduce pain or distress, reduce the number of animals used in 
experiments and replacement - use of non-animal methods whenever it is possible) by the addition of a fourth R: responsibility (Paton 1997: 240-241). Some ethicists point out the fact that it should become the main norm, sometimes calling it a super-rule (Birnbacher 1999: 88).

\section{Reasonable expectations of benefit}

One of the basic requirements for experiments on animals to be considered ethical are reasonable grounds to believe that such research will bring the desired effects. Therefore, a properly proportional reason which would justify the decision to start the procedure has to exist (Papieska Akademia Pro Vita 2012: 540). Such justifications may include the pre-clinical stages of introducing a new medical product, diagnostic method, or other forms of therapy which will be used in medicine in the future. It is clear that the use of animals in this area corresponds to their nature and does not constitute a violation of their rights.

A similar situation takes place when the intention is to test analogical procedures which are supposed to contribute to the development of veterinary medicine. Welfare of animals is not a value in its own right, although the aim should be to ensure their well-being. It is also closely related to the welfare of people as expressed by the Latin motto "Salus (sanitas) animalium pro salute hominis." For humanity makes one world with nature, including animals, and this concern has a positive reflection in each person's life (Piszcz 1996: 236).

It seems that using animals to educate future doctors, veterinarians, or other representatives of natural sciences is also a fair practice as it contributes to them gaining knowledge and skills which they will use to treat people and animals. To this end, however, it would be preferred to deviate more from conducting such research as a wide range of alternative methods exists. Sometimes, although relatively seldom, people hold a belief that only the emotional experience related to conducting research on a living animal can teach a person the respect towards the phenomenon of life (Guzek 1999: 89). It should 
be noted, however, that a student has other means of achieving this goal. Observing live animals, for instance, can serve this purpose.

A different situation occurs when none of the aforementioned circumstances are linked to the execution of an experiment, and its goal is to test the effect of substances which will not serve any important purpose, including specifically the protection of values such as life and health. This is particularly true for research that aims to reduce the negative influence of pleasurable products, mainly tobacco products and cosmetics. In such cases, the pain and stress caused to living beings is not being counterbalanced by the interests of people. Being aware of the price paid by the animals would cause a person with at least a minimal level of sensitivity to lose happiness or pleasure derived from using products created or improved as a result of the suffering of animals. In this context, the ethicists formulate a rule that not every increase in human welfare justifies causing pain to living beings (Spaemann 1997: 237).

Moreover, conducting research which serves only to satisfy the curiosity of the researcher and is not associated with any hope for the advancement of medical knowledge or practice should be considered wicked. The desire to conduct research for fun or entertainment should be assessed similarly and conducting tests motivated by the desire to cause pain is worthy of particular condemnation (Laun 2002:393).

The presented requirements entail particularly important responsibilities for the representatives of experimental sciences. Carrying out experiments on animals can never be the first stage of scientific research because there has to be a reason or hope that the experiments will bring positive results. Scientists should, therefore, be characterized by extraordinary care and conscientiousness in conducting studies and theoretical simulations (Galewicz 2009: 60). It is, therefore, necessary to become closely acquainted with the bibliographic information and request advice from other specialists to obtain confirmation of the motivation and validity of a research project (Radzikowski 1995: 18). Reliable use of these indications is an indispensable condition for the fairness of subsequent experiments on living beings. 


\section{Limiting the number of animals used in tests}

Currently it is not possible to forego scientific research using animals. That is why one of the main requests for people who plan and perform the experiments is to reduce the number of animals used for experiments. John Paul II called for this in one of his addresses to scientists: "Reducing the number of experiments performed on animals which become less and less necessary corresponds with the creation plan and the good of all Creation" (Jan Paweł II 1998: 198). In this case, the teachings of the Church correspond with the postulates made by the scientists themselves or legal acts in force in individual countries.

The scientists should take active steps to maximally reduce the number of animals used for experiments. This purpose can be achieved by carefully planning the whole experimental process, particularly beginning with a thorough overview of the world's literature so as not to repeat tests that were already carried out in another scientific center. Precise theoretical studies should also reveal the potential difficulties which may appear when conducting the experiments and influence their results. It is also preferable to hire statisticians for the research team or at least use the well-developed methods of statistics which are available thanks to the development of computerization. This, in turn, will allow for precise selection of animals as well as better analysis of the achieved results. Every animal used for testing should provide the researchers with maximum amount of information. This results in a moral duty to examine as many anatomical, behavioral or biochemical indicators as possible, including those for which there is at least a minimal suspicion that they will matter during the next stages of research (Ranganatha, Kuppast 2012: 29).

Publication of research results in international scientific journals should also serve the purpose of reducing the number of animals used in scientific experiments. This would allow the scientists to avoid needless repetitions. This just goal is, however, being impeded by concerns and companies which consider their interests only in economic terms, which often causes the results of the experiments to be highly-guarded secrets. The Church recognizes the right of companies to 
proportional returns on investments. In case of a conflict of interest when it comes to unlimited desire for gain and just postulates for the protection of animals we should always choose the latter (Jan Paweł II 2012: 198). In this context, it seems appropriate to speak in some cases about the structures of sin which are the result of the intensification of sins of greed of many people (Jan Paweł II 1984: 16).

\section{Minimization of pain and stress}

Another of the key conditions for biomedical research conducted on animals to be considered fair is reducing the pain and stress felt by the animals to a minimum. Catholic moral theology, in contrast to some representatives of ethics, does not completely reject the possibility of conducting experiments which may cause pain or death to animals. However, causing suffering without a justified cause if it can be avoided contradicts the Christian ethos and the rules of universal morality. This is particularly true for people dealing with animals every day and thus also those who take part in the experiments (Jan Paweł II 2007: 610).

This obligation is accommodated by the demand to improve research methods, which boils down to limiting or completely eliminating the pain or stress felt by the animal. The intended result can be achieved by using various methods. First and foremost a moral obligation to use anesthetics or analgesics should be emphasized, unless their negative effect on the results of the research have been proven. There is a wide range of substances which can be matched to the type of the experiments being carried out and based on it to anesthetize the animal, sedate it, or reduce the pain it feels. It is advised to stop administering the substance during toxicity tests with the occurrence of the first symptoms of side effects which allow for ascertaining indisputably that it has a negative effect on the organism. Recommendations are also being addressed to those researchers who, as part of their experiments, carry out operations or other surgical interventions. During such a procedure special consideration should be paid to observing all principles of antisepsis which will allow for preventing a significant amount of intra- and postoperative infections 
and thus contribute to saving the animals from suffering. The ethical rule that an animal should not be submitted to more than one serious operation for scientific purposes should be considered just (Ranganatha, Kuppast 2012: 29).

It is also worth noting that improving research methods by improving the welfare of laboratory animals which includes the reduction of pain, stress, and infections has also a material impact on the quality of the research conducted and allows for achieving more reliable results which, in turn, shortens the project's completion process (Baro et al 2012: 346-347).

In this context vivisections in the strict sense should also be mentioned. Performing serious surgical procedures on an animal, especially a highly developed one, which, being fully aware, feels excruciating pain should be considered an inhumane behavior which proves the person performing the procedure to be immoral (Castingone 2007: 182-183).

\section{Transgenesis}

In the face of the growing importance of genetic modifications, including among animals used for scientific purposes, an in-depth discussion about this issue becomes necessary. The transgenesis phenomenon is used to breed animals the genetic structure of which will allow for more easily extrapolating the results of the experiments to people or for procuring organs or tissues for xenotransplantation. To carry out a comprehensive analysis of these manipulations, the issues of the possibility of human interference into the genetic structure of organisms and the conditions of using them in the process of conducting scientific research has to be presented.

Humans as the only beings made in the image and likeness of God is to cooperate with God in order to give the world its final and perfect form. Humans should also, through responsible work, lead the whole Creation so that it can serve the good of each person and humanity as a whole (Papieska Akademia Pro Vita 2012: 538). This entitles people to make genetic modifications, also using human genes. 
The condition for such actions to be considered justified is to have respect for the animal and biodiversity. Such manipulations cannot interfere with the identity of an animal or species to which it belongs and their effects in the form of anatomical or behavioral changes should be possible to predict. Moreover, the possible consequences for the environment and the potential effects that may show in the offspring have to be considered. Transgenesis has to serve the purpose of achieving major benefits (Papieska Akademia Pro Vita 2012: 545 $546)$ which is the case when researching new medicine and medical techniques and preparing organs for potential transplantation. The remaining ethical requirements should be preserved in relation to the research in question, therefore, the pain and stress the animal feels should be reduced, the number of organisms being altered should be maximally limited, and organs and tissues should be procured during one procedure.

However, extra caution has to be taken when performing biomedical research with the use of transgenesis. Genetic modifications may substantially change the characteristics of animals. Sensitivity to pain and stress that is typical for a certain species is one of such characteristics. By interfering in the genetic realm the researcher may lose the only tool available to them for evaluating whether the animal is in pain (Verhoog 1998: 215; Camosy, Kopp 2014: 48-50).

\section{Maintain proportions}

The rules of ethical conduct of scientific research discussed above are closely intertwined. It is therefore essential to maintain the right balance between them. Exposing animals to considerable levels of pain and stress that is not possible to be eliminated should be considered justified if conducting the experiment was to yield substantial benefits for people. On the other hand, the possibility of achieving small benefit can only justify insignificant experimental interference (Yarri 2005: 149-151).

Therefore, the fairness of conducting experiments on animals in the field of psychology should be questioned. According to many 
scientists they do not provide a significant contribution to our knowledge of an animal's psyche. Their results are often trivial, cannot be put to practical use, and boil down to scientifically describing what everyone already knows. Additionally, such procedures expose the animal to high levels of stress which is much more difficult for the animal to endure than intense pain, especially since the specificity of such research requires it to be repeated time and again (Harlow 1962: 896; Mroczkowski 2009: 1; Trojan 2008: 139-141). Bearing in mind the necessity of respecting the nature of the animals and treating them humanely, psychologists should be encouraged to completely abandon conducting such experiments.

\section{Intention}

To properly evaluate specific forms of experiments it is also necessary to take into account the intention of the people involved in the research. The intention, that is the reason or goal for which a person undertakes to perform an action, gives it an added value which he receives from the moral object (Nowosad 1994: 115). It is therefore necessary to take into account the motivations of the scientists and their plans for future use of research results. In this case wicked intentions lie at the foundations of a negative assessment of the experiment.

The classical case of the discussed situation is conducting research related to human interference in the area of life creation the results of which are to be used in the future to work out or improve the methods of artificial insemination. Experiments related to breeding animals, with few exceptions, do not give rise to any serious moral objections. Manipulations related to animal reproduction are predominantly allowed, especially as such procedures do not cause animals to feel significant pain or stress (Mroczkowski 2009: 1). Methods originally used in veterinary medicine or zootechnics are, however, currently being used for human procreation which is a cause for serious concern and moral objections (Jan XXIII 1987: 193; Wróbel 2009: 182-199). All stages of works related to the development of methods for technical procreation should therefore be considered morally wicked. This 
statement should also refer to experiments on animals if their results are to be used for this purpose.

A very interesting method of ethical assessment of animal experimentation has been proposed by a Canadian scholar David G. Porter. He created an instrument which will assist scientists in making decisions whether to conduct an experiment or not. It is based on eight criteria, each of which is measured on a five-point scale. The criteria are related to pain or stress felt by the animal due to the experiment, the scope of the test and the manner in which it is to be conducted and the species of animals used for testing (Porter 1992: 101-102).

The scale proposed by Porter can be a valuable aid for a researcher facing a dilemma whether to conduct an experiment on animals. It takes into account most of the criteria which stem from philosophical and theological premises. It cannot, however, constitute the sole and final basis for moral evaluation of human behavior in this area. The possibility of obtaining numerous points in some criteria and few points in others and thus qualify within the acceptable range would be contrary to one of the basic principles concerning the sources of morality of the human act and its evaluation: "Bonum ex integra causa, malum ex quocumque defectu” (Wichrowicz 2002: 45).

\section{Complying with the codified law}

The rule to abide by the law introduced by the public authorities also lies within the area of moral obligations provided it meets a series of conditions. For a rule of law issued by the legitimate public authority to be binding in conscience it has to be fair, just, feasible, and necessary or truly beneficial. Regulations and limitations regarding animal experiments fall within the competence of the legislator. They comply with God's law and natural law because they contribute to the respect of Creation. They are feasible although abiding by them may require greater effort from the scientists. Finally, they serve the public interest by contributing to the development of diagnostics and therapy of diseases as well as protect against possible loss of sensitivity to painful experiences of animals (Nowosad 1994: 72). In this context, 
it must be noted that each researcher must abide by the laws governing the conduct of research and that the possible transgressions of those laws incur moral guilt. The fact that both the legislation of Poland and the European Community largely take into account the ethical criteria and postulates formulated in this article is to be welcomed.

To sum up the obligations that apply to scientists who conduct animal experiments it should be noted that fulfilling the obligations under discussion not only gives them peace of mind. It also contributes to their responsible mission gaining prestige (Radzikowski 2008: 24). This is especially important these days, when the representatives of the world of science do not enjoy a high social prestige. For the sake of its growth they should take all available measures to change this trend.

\section{References}

Baro M., de Llobet L.I., Modollel I., Guedea F., Visa J., Balart J., 2012, Development and Refinement of a Technique Using a Medical Radiation Therapy Facility to Irradiate Immunideficient Mice Bearing Xenografted Human Tumours, Laboratory Animals, vol. 46, 346-348.

Birnbacher D., 1999, Tierversuche - ethische Aspekte, Lingua ac Communitas, vol. 9, 87-102.

Camosy Ch.C, Kopp S., 2014, "The Use of Non-Human Animals in Biomedical Research. Can Moral Theology Fill the Gap?" Journal of Moral Theology, vol. 3, 37-55.

Castingone S., 2007, La vivisezione degli animali, in: G. Russo (red.), "Fondamenti di bioetica animale", Elledici, Milano, 181-185.

Galewicz W., 2009, O etyce badań naukowych, w: Galewicz W. (red.), „Etyczne i prawne granice badań naukowych”, Universitas, Kraków, 59-69.

Guzek J.W., 1999, Human-Animal Relationship. Human Health and Animal Experimentation, "Dialogue and Universalism", vol. 9-10, 83-96. 
Harlow H.F., 1962, Fundamental Principles for Preparing Psychology Journal Article, Journal of Comparative and Physiological Psychology, vol. 55, 893-896.

Hendricks M., 2001, O właściwą postawę wobec zwierząt, L'Osservatore Romano, vol. 10, 53-55.

Jan Paweł II, 1984, Adhortacja apostolska Reconciliatio et paenintentia, Libreria Editrice Vaticana, Rzym.

Jan Paweł II, 1998, Eksperyment w biologii. Przemówienie do uczestników Tygodnia Studiów zorganizowanego przez Papieską Akademię Nauk (23.10.1982), w: Szczygieł K. (red.), „W trosce o życie. Wybrane dokumenty Stolicy Apostolskiej”, Biblos Kraków, 196-199.

Jan Paweł II, 2007, W używaniu i produkcji lekarstw należy przestrzegać zasad moralnych. Przemówienie do uczestników konferencji na temat lekarstw (24.10.1986), w: „Nauczanie papieskie”, vol. 9, Pallottinum, Poznań, 609-611.

Jan Paweł II, 2012, Konflikt interesów i jego znaczenie w nauce i medycynie. Przesłanie do uczestników międzynarodowej konferencji zorganizowane w Warszawie (5.04.2002). w: Brusiło J. (red.), „W trosce o życie. Wybrane dokumenty Stolicy Apostolskiej”, vol. 2, Biblos, Tarnów, 198-200.

Jan XXIII, 1987, Encyklika Mater et Magistra, w: Radwan M., Dyczewski L., Stanowski A. (red.), „Dokumenty nauki społecznej Kościoła”, vol. 1, Redakcja Wydawnictw KUL, Lublin, 221-268.

Katechizm Kościoła Katolickiego, 2002, Pallottinum, Poznań.

Laun A., 2002, Współczesne zagadnienia teologii moralnej. Teologia moralna - zagadnienia szczegółowe, Wydawnictwo „M”, Kraków.

Morciniec P., 2005, Status zwierząt w kontekście możliwości ksenotransplantacji. Forum Teologiczne, vol. 6, 75-93.

Mroczkowski S., 2009, Cierpienie zwierząt doświadczalnych, Przegląd Hodowlany, 77, 1-3.

Nowosad S., 1994, Teologia moralna ogólna. Skrypt dla stuchaczy Kolegium Teologicznego, RWKUL, Lublin..

Papieska Akademia Pro Vita, 2012, Szanse dla ksenotransplantacji. Aspekty naukowe i względy etyczne, w: Brusiło J. (red.), „W trosce 
o życie. Wybrane dokumenty Stolicy Apostolskiej”, vol. 2, Biblos, Tarnów, 528-551.

Paton W.D.M., 1997, Człowiek i mysz. Badania medyczne na zwierzętach. Wydawnictwo PWN, Warszawa.

Piszcz E., 1996, Homilia wygłoszona podczas Mszy św., Życie Weterynaryjne, vol. 71, 236.

Porter D.G., 1992, Ethical Scores for Animal Experiments, Nature, vol. 365, 101-102.

Radzikowski C., 1995, Ocena tzw. metod alternatywnych $w$ badaniach biomedycznych, w: Fiałek E. (red.), „Eksperymenty na zwierzętach. Wspólna konferencja Komitetu Etyki w Nauce PAN i Komisji Etyki Medycznej PAU. Warszawa 21 listopada 1994 r.”, Polska Akademia Umiejętności, Kraków, 17-26.

Ranganatha N., Kuppast I.J., 2012, A Review on Alternatives to Animal Testing Methods in Drug Development, International Journal of Pharmacy and Pharmaceutical Sciences, vol. 4, 28-32.

Spaemann R., 1997, Szczęście a życzliwość. Esej o etyce, RWKUL, Lublin.

Trojan M., 2008, Przepisy prawne a badania psychologiczne z udziałem zwierzat. w: Łukasiewicz M. (red.), „Konferencja Naukowa "Zwierzęta w badaniach naukowych". SGGW 18-19 września 2008”, Polska Akademia Nauk. Instytut Genetyki i Hodowli Zwierząt, Jastrzębiec, 139-141.

Verhoog H., 1998, Moralność a „naturalność" zwierząt transgenicznych, Ethos, vol. 11, 215-227.

Wichrowicz C.J., 2002, Zarys teologii moralnej w ujęciu tomistycznym, Wyd. „M”, Kraków.

Wróbel J., 2009, Prokreacja technicyzowana - wyzwania etyczne, Roczniki Teologii Moralnej, vol. 1, 183-202.

Yarri D., 2005, The Ethics of Animal Experimentation. A Critical Analysis and Constructive Christian Proposal, Oxford University Press, Oxford. 